\title{
Brain Arousal and Information Theory
}





\section{Brain Arousal and Information Theory}

\section{Neural and Genetic Mechanisms}

\section{Donald Pfaff}

Harvard University Press

Cambridge, Massachusetts and London, England 2006 
Copyright () 2006 by the President and Fellows of Harvard College

All rights reserved.

Printed in the United States of America

Library of Congress Cataloging-in-Publication Data

Pfaff, Donald W., 1939-

Brain arousal and information theory : neural and genetic mechanisms /

Donald Pfaff.

p. ; cm.

Includes bibliographical references and index.

ISBN 0-674-01920-2 (cloth : alk. paper)

1. Arousal (Physiology) 2. Information theory. 3. Neurogenetics.

4. Neurophysiology. I. Title.

[DNLM: 1. Arousal-physiology. 2. Nerve Net-physiology. 3. Neurobiology.

WL 103 P523b 2006]

QP405.P43 2006

$153-\mathrm{dc} 22 \quad 2005046338$ 